Provided for non-commercial research and education use. Not for reproduction, distribution or commercial use.

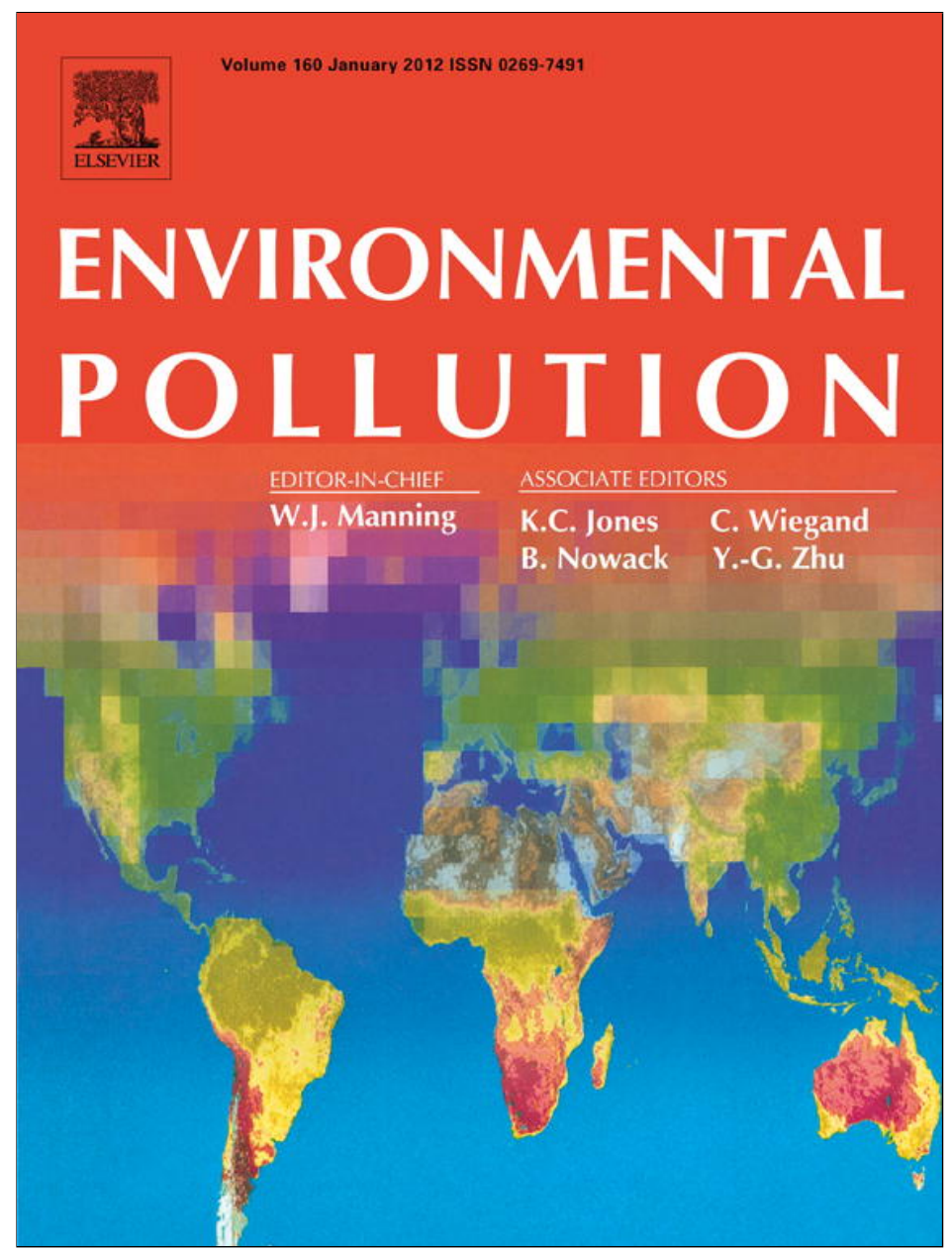

(This is a sample cover image for this issue. The actual cover is not yet available at this time.)

This article appeared in a journal published by Elsevier. The attached copy is furnished to the author for internal non-commercial research and education use, including for instruction at the authors institution and sharing with colleagues.

Other uses, including reproduction and distribution, or selling or licensing copies, or posting to personal, institutional or third party websites are prohibited.

In most cases authors are permitted to post their version of the article (e.g. in Word or Tex form) to their personal website or institutional repository. Authors requiring further information regarding Elsevier's archiving and manuscript policies are encouraged to visit:

http://www.elsevier.com/copyright 


\title{
Impacts of warming on aquatic decomposers along a gradient of cadmium stress
}

\author{
D. Batista, C. Pascoal, F. Cássio* \\ Centre of Molecular and Environmental Biology (CBMA), Department of Biology, University of Minho, Campus de Gualtar, 4710-057 Braga, Portugal
}

\section{A R T I C L E I N F O}

\section{Article history:}

Received 8 February 2012

Received in revised form

9 May 2012

Accepted 13 May 2012

\section{Keywords:}

Aquatic fungi

Invertebrate shredders

Cadmium

Global warming

Litter decomposition

\begin{abstract}
A B S T R A C T
We evaluated the effects of cadmium and temperature on plant-litter decomposition by examining diversity and activity of aquatic fungi and leaf consumption by Limnephilus sp., a typical invertebrate shredder of Iberian streams. Freshly fallen leaves were immersed in a stream to allow microbial colonization, and were exposed in microcosms to a gradient of cadmium ( $\leq 11$ levels, $\leq 35 \mathrm{mg} \mathrm{L}^{-1}$ ). Microcosms were kept at $15{ }^{\circ} \mathrm{C}$, a temperature typically found in Iberian streams in autumn, and at $21^{\circ} \mathrm{C}$ to simulate a warming scenario. The increase in temperature stimulated leaf decomposition by microbes, fungal reproduction and leaf consumption by the shredder. Conversely, increased cadmium concentrations inhibited fungal reproduction and diversity, and leaf consumption by the invertebrate. Cadmium concentration inhibiting $50 \%$ of fungal reproduction, microbial decomposition and leaf consumption by the shredder was higher at $15^{\circ} \mathrm{C}$ than at $21^{\circ} \mathrm{C}$, suggesting that higher temperatures can lead to increased metal toxicity to aquatic decomposers.
\end{abstract}

(c) 2012 Elsevier Ltd. All rights reserved.

\section{Introduction}

The predicted increase in temperature, up to $6^{\circ} \mathrm{C}$ till 2100 (IPCC, 2007), is expected to affect organisms and ecological processes in both terrestrial and aquatic ecosystems (Petchey et al., 1999; Parmesan and Yohe, 2003). Moreover, climate models predict an increase in the frequency and magnitude of extreme weather events, such as drought periods and intense rainfalls (Jentsch et al., 2007), changing the levels and bioavailability of contaminants in freshwaters as a result of runoff events from the surrounding soils. Metal contamination is an environmental problem in both developing and developed countries throughout the world. Metals can reach surface and ground waters by the leaching of ores and contaminated soils or through industrial activities. Pollution by metals is a matter of great concern because of its toxicity to living organisms and persistence in the environment. Cadmium (Cd) is considered one of the most toxic metals even at micro grams per litre level, and it can accumulate in aquatic organisms (Wang et al., 2009; Schaller et al., 2010).

In freshwaters, plant-litter decomposition is an important ecosystem process, which depends on the activity of microbial decomposers and invertebrate shredders (Graça, 2001; Pascoal et al., 2005). Fungi, particularly aquatic hyphomycetes, are known to play a key role in litter decomposition in streams (Baldy et al.,

\footnotetext{
* Corresponding author.

E-mail address: fcassio@bio.uminho.pt (F. Cássio).
}

2002; Pascoal and Cássio, 2004), and to enhance litter nutritional value for invertebrate shredders (Graça, 2001).

Higher stream water temperature can affect litter decomposition directly by promoting leaching of soluble compounds (Chergui and Pattee, 1990), and indirectly by enhancing microbial activity (Fernandes et al., 2009a) or stimulating leaf consumption by invertebrate shredders (Gonzalez and Graça, 2003; AzevedoPereira et al., 2006). Increased temperature can stimulate the productivity of fungal assemblages on leaves (Suberkropp and Weyers, 1996), and the growth and reproduction of some aquatic hyphomycete species (Rajashekar and Kaveriappa, 2000; Dang et al., 2009), resulting in faster litter decomposition (Fernandes et al., 2009a; Ferreira and Chauvet, 2011). The increase in temperature may also change the feeding behaviour of invertebrate shredders and the individual body elemental composition (Ferreira et al., 2010).

Several studies have demonstrated that metals, above a certain threshold concentration, can negatively affect the diversity and activity of aquatic hyphomycetes and depress plant-litter decomposition in streams (Sridhar et al., 2001; Duarte et al., 2004, 2008). Metals can also compromise survival, growth and reproduction of several invertebrate species (Barata and Baird, 2000; Vogt et al., 2007) and reduce the consumption rates of many invertebrates at environmentally realistic concentrations (Riddell et al., 2005; Felten et al., 2008).

In manipulative experiments, the effects of environmental stressors are usually tested individually and mostly targeting specific organisms. However, in natural ecosystems organisms are 
exposed to several stressors simultaneously and may not always respond as predicted from studies that used only single stressors (Duarte et al., 2008; Fernandes et al., 2009b). Moreover, studies based on organismal responses to stressors are clearly insufficient to predict the impact of stressors to the entire community and associated ecological processes. Therefore, studies at the community and multitrophic levels are warranted if we are to elucidate the combined effects of stressors on ecosystem functioning.

Higher temperatures can lead to increased toxicity of chemicals in conventional ecotoxicity experiments (Heugens et al., 2006), but the potential impacts on communities or processes in which organisms are involved have been seldom examined. We investigated the interactive effects of $\mathrm{Cd}$ and temperature on plant-litter decomposition by examining (1) leaf-associated fungal assemblages, and (2) the feeding behaviour of invertebrate shredders. Litter associated microbial assemblages were exposed to a gradient of Cd (11 levels, $\left.\leq 35 \mathrm{mg} \mathrm{L}^{-1}\right)$ under two temperature regimes (ambient $15{ }^{\circ} \mathrm{C}$ and $21^{\circ} \mathrm{C}$ to simulate a warming scenario), and fungal diversity and activity on decomposing leaves were monitored. In parallel, we conducted a feeding experiment where a common invertebrate shredder was allowed to feed on microbially-colonized leaves while exposed to metal and temperature treatments. Finally, we conducted a post-exposure feeding experiment to assess the invertebrate ability to recover after release from metal stress. We hypothesized that a $6{ }^{\circ} \mathrm{C}$ increase in temperature would stimulate fungal and invertebrate activity on decomposing leaves, while the opposite would occur under $\mathrm{Cd}$ stress. Because a rise in temperature may result in an increase in metal uptake by the organisms, we expected that warming would exacerbate the impacts of metals on detritus food-webs.

\section{Materials and methods}

\subsection{Sampling site and microbial colonization of leaves}

The sampling site was in the Algeriz Stream (Cávado River basin), a low-orde stream in NW Portugal $\left(41^{\circ} 350^{\prime} \mathrm{N} 8^{\circ} 220^{\prime} \mathrm{W}\right)$. The riparian vegetation is dominated by Eucalyptus globulus Labill. and Pteridium aquilinum Khun, and it also includes Alnus glutinosa (L.) Gaertn. and Quercus robur L. The stream bottom is composed by boulders, pebbles and sand.

Conductivity, $\mathrm{pH}$ and dissolved oxygen were measured in situ using a Multiline F/set 3 no. 400327 (WTW). Stream water had low conductivity $\left(43 \mu \mathrm{S} \mathrm{cm}^{-1}\right)$, high dissolved oxygen concentration (100\% saturation) and was slightly acidic (pH 6.8 ). Stream water samples were collected in glass bottles, transported in a cool box $\left(4^{\circ} \mathrm{C}\right)$, for quantification of inorganic nutrient concentrations with a HACH DR/2000 spectrophotometer (Hach, Loveland, $\mathrm{CO}$ ) according to the manufacture protocols. Concentrations of nutrients were: $0.06 \mathrm{mg} \mathrm{NO}-{ }_{3}^{-}-\mathrm{N} \mathrm{L}^{-1}, 0.001 \mathrm{mg} \mathrm{NO}-\overline{2}-\mathrm{N} \mathrm{L}^{-1}$ $<0.01 \mathrm{mg} \mathrm{NH}_{3}-\mathrm{N} \mathrm{L}^{-1}$, and $0.03 \mathrm{mg} \mathrm{PO}_{4}^{3-}-\mathrm{P} \mathrm{L}^{-1}$. Additional stream water samples were collected, filtered to retain suspended solids, and autoclaved $\left(120^{\circ} \mathrm{C}, 20 \mathrm{~min}\right.$ ) for the microcosm experiments.

In September 2009, leaves of A. glutinosa (alder) were collected immediately before abscission and dried at room temperature. The leaves were soaked in deionised water and cut into $12 \mathrm{~mm}$ diameter disks. Sets of leaf disks were placed into $0.5 \mathrm{~mm}$ mesh bags $(16 \times 20 \mathrm{~cm})$ and were immersed in the stream to allow microbial colonization. After 7 days, leaf bags were retrieved and transported to the laboratory in a cool box for microcosm experiments.

\subsection{Leaf decomposition by microbes}

Fifty leaf disks from each bag were rinsed with deionised water and placed in $150 \mathrm{~mL}$ Erlenmeyer flasks. Three replicate microcosms were supplemented with $\mathrm{Cd}$ (0.015, 0.1, 0.5, 1, 1.5, 3.5, 4.5, 10, 20, $35 \mathrm{mg} \mathrm{L}^{-1}$; added as chlorides, Sigma); $\mathrm{Cd}$ solutions were prepared in sterile stream water, and a final volume of $70 \mathrm{~mL}$ was used per microcosms. Three additional microcosms not supplemented with $\mathrm{Cd}$ were used as a negative control. One set of microcosms was incubated at $15{ }^{\circ} \mathrm{C}$ and another set at $21{ }^{\circ} \mathrm{C}$ (total of 66 microcosms). All microcosms were kept under shaking $(120 \mathrm{rpm})$ for 20 days. Solutions were renewed every 4 days and conidial suspensions were preserved in formaldehyde ( $2 \%$ final concentration) until fungal conidia were identified and counted. At the end of the experiment (after 20 days), leaf disks were harvested for estimation of leaf mass loss, fungal sporulation, biomass and diversity.

\subsection{Fungal sporulation and biomass}

Conidial suspensions were mixed with $200 \mu \mathrm{L}$ of $0.5 \%$ Tween 80 and appropriate volumes were filtered ( $5 \mu \mathrm{m}$ pore size, Millipore, Billerica, MA). Conidia on the filters were stained with $0.05 \%$ cotton blue in lactic acid. To determine the contribution of each aquatic hyphomycete species to the total conidial production, approximately 300 conidia per filter were identified and counted under a light microscope $(400 \times$, Leica Biomed, Heerbrug, Switzerland).

Six leaf disks from each replicate were used for quantification of litter ergosterol concentrations as a surrogate for fungal biomass (Gessner, 2005). Lipids were extracted from leaf disks by heating $\left(80^{\circ} \mathrm{C}, 30 \mathrm{~min}\right)$ in $0.8 \%$ of $\mathrm{KOH} / \mathrm{methanol}$, and the extract was partially purified by solid-phase extraction. Ergosterol was quantified by high-performance liquid chromatography (HPLC) using a LiChrospher RP18 column ( $250 \mathrm{~mm} \times 4 \mathrm{~mm}$, Merck), connected to a liquid chromatographic system (Beckmann Gold System, Brea, CA). The system was run isocratically with HPLCgrade methanol at $1.4 \mathrm{~mL} \mathrm{~min}{ }^{-1}$ and $33{ }^{\circ} \mathrm{C}$. Ergosterol was detected at $\lambda=282 \mathrm{~nm}$ and its concentration was estimated using standard series of ergosterol (Fluka) in isopropanol.

\subsection{Fungal diversity from DNA fingerprints}

DNA was extracted from three leaf disks using a soil DNA extraction kit (MoBio Laboratories, Solana Beach, CA) according to the manufacturer instructions. The ITS2 region of fungal rDNA was amplified with the primer pairs ITS3GC and ITS4 as described in Duarte et al. (2008). The forward primer had an additional 40-bp GC tail on the $5^{\prime}$ end, which ensures separation during denaturing gradient gel electrophoresis (DGGE) gel (Duarte et al., 2008). For polymerase chain reaction (PCR) of fungal DNA, $12.5 \mu \mathrm{L}$ of Go Taq, $0.5 \mu \mathrm{L}$ of each primer, $1 \mu \mathrm{L}$ of DNA and $10.5 \mu \mathrm{L}$ of ultra pure water were used in a final volume of $25 \mu \mathrm{L}$. PCR reagents were from Promega except primers that were from Stabvida. DNA amplification was carried out in a MyCycler Thermal Cycler (BioRad Laboratories, Hercules, CA, USA) using the following program: initial denaturation at $95{ }^{\circ} \mathrm{C}$ for $2 \mathrm{~min}$; followed by 36 cycles of denaturation at $95{ }^{\circ} \mathrm{C}$ for $30 \mathrm{~s}$, primer annealing at $55^{\circ} \mathrm{C}$ for $30 \mathrm{~s}$, and extension at $72{ }^{\circ} \mathrm{C}$ for $1 \mathrm{~min}$. Final extension was at $72{ }^{\circ} \mathrm{C}$ for $5 \mathrm{~min}$ (Duarte et al., 2008).

DGGE analysis was performed using a DCodeTM Universal Mutation Detection System (BioRad Laboratories). Samples of $20 \mu \mathrm{L}$ from the amplification products of $380-400$ bp were loaded on $8 \%(\mathrm{w} / \mathrm{v})$ polyacrylamide gel in $1 \times$ Tris-acetate-EDTA (TAE) with a denaturing gradient from 30 to $70 \%$. The gels were run at $55 \mathrm{~V}, 56{ }^{\circ} \mathrm{C}$ for $16 \mathrm{~h}$ and stained with $10 \mu \mathrm{L}$ of Gel Star (Lonza) for $10 \mathrm{~min}$. The gel images were captured under UV light in a transilluminator Eagle eye II (Stratagene, La Jolla, CA, USA)

\subsection{Feeding experiment}

Feeding experiments were performed with the invertebrate Limnephilus sp. (Trichoptera: Limnephilidae) because animals of this genus are common in Iberian streams and easy to maintain in the laboratory. The animals were collected at an unpolluted site of the Cávado River (NW Portugal) and acclimated in the laboratory under aerated stream water, at $15^{\circ} \mathrm{C}$, with a supply of alder leaves. The animals were kept under starvation for $24 \mathrm{~h}$ before exposure to stream water supplemented or not with $\mathrm{Cd}$ and microbially-colonized leaf disks. Microbial colonization was achieved as above, by immersing leaf disks ( $12 \mathrm{~mm}$ diameter) in the stream for 7 days. Leaf disks were then exposed or not to $C d$ treatments $\left(0,0.5\right.$ and $10 \mathrm{mg} \mathrm{L}^{-1} ; 11$ replicates) at $15^{\circ} \mathrm{C}$ and $21^{\circ} \mathrm{C}$, for 20 days, before being offered to the animals. For each replicate, 1 animal ( $14.5 \pm 1.8 \mathrm{~mm}$ length) and 12 leaf disks were placed in $250 \mathrm{~mL}$ Erlenmeyer flasks containing $150 \mathrm{~mL}$ of Cd solutions. All microcosms were aerated with ai pumps for 6 days. Solutions were renewed every 3 days to remove excreted compounds and survivorship was registered twice a day during the experiment. At the end of the experiment, leaf disks and animals were frozen and lyophilized to a constant weight.

\subsection{Post-exposure feeding experiment}

For each replicate, 5 animals were placed in $500 \mathrm{~mL}$ Erlenmeyer flask containing $250 \mathrm{~mL}$ of different $\mathrm{Cd}$ concentrations $\left(0,0.015,0.05,0.1,0.5,1,3.5,10,20,35 \mathrm{mg} \mathrm{L}^{-1}\right.$; 3 replicates) and kept under aeration at $15{ }^{\circ} \mathrm{C}$. The shredders were kept under starvation for 4 days while exposed to $\mathrm{Cd}$. Then, animals were released from the metal, by transferring them to microcosms with stream water without added $\mathrm{Cd}$, and were allowed to feed for 5 days on microbially-colonized leaf disks (20 disks; $12 \mathrm{~mm}$ diameter) non-contaminated with $\mathrm{Cd}$. Leaf disks were colonized by microbial decomposers as above, by immersing the leaves in the stream for 7 days followed by 20 days in microcosms without added $\mathrm{Cd}$. At the end of the experiment, leaf disks were frozen and lyophilized before weighed to estimate leaf consumption rates.

\subsection{Leaf mass loss}

Before and after animal feeding, leaf disks from each replicate were frozen and lyophilized to a constant weight. Sets of non-colonized leaf disks were used to estimate the initial dry mass of leaves. 
2.8. Metal analysis

Lyophilized leaf disks, cases and animals from each treatment in the feeding experiment were ashed at $500{ }^{\circ} \mathrm{C}(>8 \mathrm{~h})$ and digested with nitric acid $(1 \mathrm{~mL}, 10 \%)$ and hydrochloric acid ( $1 \mathrm{~mL}, 10 \%)$ for quantification of $\mathrm{Cd}$ concentrations. Cadmium concentrations in the leaves, cases and larvae were analyzed using inductively coupled plasma-atomic emission spectrometry (ICP-AES) at the Scientific and Technological Research Assistance Centre (CACTI, University of Vigo, Spain).

\subsection{Data analysis}

The effects of $\mathrm{Cd}$ and temperature on leaf mass loss, fungal biomass and reproduction were tested by two-way analyses of variance (Two-way ANOVA) followed by Bonferroni post-tests (Zar, 1996). Data were homoscedastic and had a normal distribution, so no data transformation was done.

DGGE gels were aligned and the relative intensity of the bands in the gel was analyzed with Bionumerics software (Applied Maths, Sint-Martens-Latem, Belgium). Each DGGE band was considered an operational taxonomic unit (OTU). Cluster analyses of fungal community structure, assessed as sporulating species or OTUs from DGGE fingerprints, were done by unweighted pair-group method average (UPGMA) using the Pearson correlation coefficient.

ANOVAs were done with Graph Pad Prism 5 (GraphPad software Inc., San Diego, CA) and Cluster analyses with CANOCO 4.5 (Microcomputer Power, NY, USA).

The length of the case of each animal was measured using a stereo microscope (Leica ZOOM 2000) before the experiment, and the animal dry mass was estimated by linear regression as $\mathrm{DM}=0.0029 \times \mathrm{CO}-0.0293\left(r^{2}=0.73, p<0.05, n=36\right)$, where DM is the animal dry mass $(\mathrm{g})$ and CO is the length of the case $(\mathrm{mm})$. Relative growth rates (RGR) of the animals ( $g$ animal dry mass $g^{-1}$ animal dry mass day ${ }^{-1}$ ) were calculated as $R G R=D_{g} /\left(D_{f} \times t\right)$, where $D_{g}$ is the dry mass gained during the elapsed time $(t)$ given by the difference between final and initial dry mass $(\mathrm{g})$ and $\mathrm{DM}_{\mathrm{f}}$ is the final dry mass ( $\mathrm{g}$ ) (Ferreira et al., 2010). Relative consumption rates (RCR, g leaf dry mass $\mathrm{g}^{-1}$ animal dry mass day $^{-1}$ ) were calculated as RCR $=$ Le/ $\left(\mathrm{DM}_{\mathrm{f}} \times t\right)$, where Le is the litter dry mass eaten during the elapsed time $(t)$ and $\mathrm{DM}_{\mathrm{f}}$ is the final dry mass of animals (Ferreira et al., 2010). Leaf disks were weighed before and after being offered to the invertebrates.

The median effect concentration $\left(\mathrm{EC}_{50}\right)$, i.e. the concentration of $\mathrm{Cd}$ promoting $50 \%$ of effects, was estimated by probit analysis with SPSS software (Version 17.0 for windows, SPSS Inc, Chicago, USA). Data are presented as mean with 95\% confidence limits.

\section{Results}

During the whole study, 19 sporulating fungal taxa were found on decomposing alder leaves. The dominant fungal species was Articulospora tetracladia, followed by Tetrachaetum elegans and
Infundibura sp. (Table 1). Alatospora acuminata, Anguillospora filiformis and Tetrachaetum elegans were absent at high Cd concentrations ( $\mathrm{Cd} \geq 1.5 \mathrm{mg} \mathrm{L}^{-1}$ ), whereas Triscelosphorus cf. acuminatus became dominant. Tricladium attenuatum was only present at $15^{\circ} \mathrm{C}$, while Clavariopsis aquatica was only present at $21^{\circ} \mathrm{C}$ (Table 1 ).

In microcosms without $\mathrm{Cd}$ addition, estimates of fungal diversity were higher based on number of OTUs from DGGE fingerprints (19 and 17 OTUs at $15^{\circ} \mathrm{C}$ and $21^{\circ} \mathrm{C}$, respectively) than from analysis of spores produced (15 fungal taxa at both temperatures) (Table 1 ). The exposure to increased $\mathrm{Cd}$ concentrations led to a decrease in fungal diversity, mainly when assessed as sporulating species (Table 1).

Cluster analysis of sporulating fungal taxa (Fig. 1a) and DGGE fingerprints (Fig. 1b) showed that fungal assemblages were mainly structured by $\mathrm{Cd}$. In a general way, fungal assemblages exposed to the highest Cd concentration separated from the others. Moreover, assemblages exposed to low $\mathrm{Cd}$ concentrations grouped together and were separated from those exposed to intermediate $\mathrm{Cd}$ concentrations. At each metal concentration, temperature also discriminated fungal assemblages (Fig. 1a, b).

After 20 days in microcosms without $\mathrm{Cd}$ addition, fungal sporulation rates on leaves were $0.8 \times 10^{6}$ and $1.1 \times 10^{6}$ spores $^{-1}$ leaf dry mass day ${ }^{-1}$ at $15{ }^{\circ} \mathrm{C}$ and $21{ }^{\circ} \mathrm{C}$, respectively (Fig. 2a). Fungal sporulation was stimulated by temperature but reduced by $\mathrm{Cd}$, especially at concentrations higher than $0.5 \mathrm{mg} \mathrm{L}^{-1}$ (two-way ANOVA, $p<0.0001$ and $p=0.0004$, respectively; Bonferroni tests, $p<0.05)$. Temperature and $\mathrm{Cd}$ interactions were not significant $(p=0.083)$. The metal concentration that inhibited sporulation rate by $50 \%$ was higher at $15^{\circ} \mathrm{C}\left(\mathrm{EC}_{50}=1.889 \pm 0.006 \mathrm{mg} \mathrm{Cd} \mathrm{L}^{-1}\right)$ than at $21{ }^{\circ} \mathrm{C}\left(\mathrm{EC}_{50}=1.685 \pm 0.001 \mathrm{mg} \mathrm{Cd} \mathrm{L}{ }^{-1}\right)$.

Fungal biomass on alder leaves ranged from 185 to $226 \mu$ g ergosterol $\mathrm{g}^{-1}$ leaf dry mass in control microcosms (Fig. 2b). Fungal biomass was affected by Cd concentration, but not by temperature or interaction between factors (two-way ANOVA, $p<0.0001, p=0.427$ and $p=0.117$, respectively). Consistently, the $\mathrm{EC}_{50}$ of $\mathrm{Cd}$ for fungal biomass was similar at both temperatures $\left(\mathrm{EC}_{50}=12.39 \pm 0.01\right.$ and $12.29 \pm 0.005 \mathrm{mg} \mathrm{L}^{-1}$ for $15^{\circ} \mathrm{C}$ and $21^{\circ} \mathrm{C}$, respectively). Cadmium at concentrations $\geq 10 \mathrm{mg} \mathrm{L}^{-1}$ inhibited

Table 1

Percentage contribution of each fungal taxon to the total conidial production on alder leaves colonized in the Algeriz Stream and then exposed for 20 days in microcosms to different $\mathrm{Cd}$ concentrations at $15^{\circ} \mathrm{C}$ and $21^{\circ} \mathrm{C}$.

\begin{tabular}{|c|c|c|c|c|c|c|c|c|c|c|c|}
\hline \multicolumn{12}{|l|}{ Cd concentration $\left(\mathrm{mg} \mathrm{L}^{-1}\right)$} \\
\hline \multirow[t]{2}{*}{ Fungal taxa } & \multicolumn{11}{|c|}{$15^{\circ} \mathrm{C} / 21^{\circ} \mathrm{C}$} \\
\hline & 0 & 0.015 & 0.1 & 0.5 & 1 & 1.5 & 3.5 & 4.5 & 10 & 20 & 35 \\
\hline Alatospora acuminata Ingold & $0.2 / 0.1$ & $0.4 / 0.1$ & $0.1 / 0.1$ & $0.1 / 0.3$ & $-/ 0.1$ & $-1-$ & $-1-$ & $-1-$ & $-1-$ & $-1-$ & $-1-$ \\
\hline Alatospora pulchella Marvanová & $4.4 / 5.9$ & $6.0 / 6.6$ & $5.5 / 8.4$ & $8.2 / 16.3$ & $15.5 / 16.5$ & $14.5 / 26.7$ & $36.1 / 67.9$ & $34.5 / 71.4$ & $7.1 /-$ & $-1-$ & $-1-$ \\
\hline Anguillospora filiformis Greath. & $4.0 / 1.9$ & $1.2 / 1.1$ & $3.0 / 2.3$ & $0.7 / 0.4$ & $0.4 / 0.7$ & $1.3 / 0.1$ & $-1-$ & $-1-$ & $-1-$ & $-1-$ & $-1-$ \\
\hline Articulospora tetracladia Ingold & $38.7 / 47.8$ & $48.2 / 45.3$ & $42.3 / 46.7$ & $53.8 / 39.3$ & $33.4 / 44.6$ & $28.8 / 36.6$ & $15.9 / 17.7$ & $2.6 / 8.6$ & $14.3 / 30.8$ & $-/ 62.5$ & $-1-$ \\
\hline Clavariopsis aquatica De Wild. & $0.2 / 0.3$ & $-/ 0.3$ & $-/ 0.1$ & $-/ 0.3$ & $-/ 0.1$ & $-/ 0.2$ & $-1-$ & $-1-$ & $-1-$ & $-1-$ & $-1-$ \\
\hline Cylindrocarpon sp. & $-1-$ & $-1-$ & $-1-$ & $-1-$ & $0.3 /-$ & $0.3 / 0.1$ & $0.1 / 1.2$ & $0.7 / 4.9$ & $42.9 / 46.2$ & $-1-$ & $-1-$ \\
\hline Flabellospora acuminata Descals & $-1-$ & $0.1 /-$ & $-1-$ & $0.1 /-$ & $-1-$ & $0.1 /-$ & $0.1 /-$ & $0.4 /-$ & $-/ 15.4$ & $-1-$ & $-/ 50.0$ \\
\hline Fusarium sp. & $-1-$ & $0.1 /-$ & $-1-$ & $0.1 /-$ & $-1-$ & $-/ 0.1$ & $0.1 / 0.3$ & $1.3 /-$ & $14.3 / 7.7$ & $16.7 / 25.0$ & $-1-$ \\
\hline Infundibura sp. & $15.2 / 19.2$ & $12.2 / 20.9$ & $16.5 / 3.7$ & $0.1 / 0.2$ & $-/ 0.1$ & $-1-$ & $-1-$ & $-1-$ & $-1-$ & $33.3 /-$ & $-1-$ \\
\hline Lemonniera aquatica De Wild. & $5.2 / 4.3$ & $4.3 / 4.5$ & $4.1 / 4.8$ & $3.7 / 7.3$ & $8.0 / 6.4$ & $3.4 / 5.7$ & $4.1 / 3.0$ & $3.5 / 4.9$ & $-1-$ & $-1-$ & $-1-$ \\
\hline Lunulospora curvula Ingold & $4.4 / 4.1$ & $5.8 / 3.5$ & $6.3 / 5.0$ & $4.0 / 11.5$ & $3.2 / 12.6$ & $2.0 / 14.3$ & $2.9 / 1.7$ & $2.2 / 3.3$ & $-1-$ & $-1-$ & $-1-$ \\
\hline Tetrachaetum elegans Ingold & $25.2 / 14.4$ & $18.6 / 14.7$ & $20.8 / 27.3$ & $28.0 / 23.2$ & $36.4 / 17.5$ & $47.9 / 12.4$ & $37.1 / 5.5$ & $50.9 / 4.3$ & $-1-$ & $-1-$ & $-1-$ \\
\hline Tetracladium breve A. Roldán & $0.1 / 0.4$ & $0.5 / 0.3$ & $0.21-$ & $0.3 / 0.1$ & $0.4 /-$ & $0.1 /-$ & $0.3 / 0.1$ & $0.2 /-$ & $-1-$ & $-1-$ & $-1-$ \\
\hline Tricladium attenuatum S.H. Iqbal & $-1-$ & $0.8 /-$ & $0.1 /-$ & $0.1 /-$ & $-1-$ & $-1-$ & $-1-$ & $-1-$ & $-1-$ & $-1-$ & $-1-$ \\
\hline Tricladium chaetocladium Ingold & $0.8 / 0.4$ & $0.2 / 0.1$ & $0.4 / 0.1$ & $0.3 / 0.1$ & $-1-$ & $0.4 / 0.4$ & $1.0 / 0.3$ & $0.4 / 0.4$ & $7.1 /-$ & $-1-$ & $-1-$ \\
\hline Tricladium splendens Ingold & $0.4 / 0.1$ & $0.8 / 0.5$ & $0.6 / 0.6$ & $0.3 / 0.3$ & $1.8 / 0.5$ & $1.0 / 0.3$ & $1.8 / 1.2$ & $2.4 / 1.0$ & $-1-$ & $-1-$ & $-1-$ \\
\hline Triscelosphorus cf. acuminatus Ingold & $0.4 / 0.3$ & $-/ 1.5$ & $0.1 / 0.6$ & $0.1 / 0.5$ & $0.3 / 0.8$ & $0.1 / 3.1$ & $0.3 / 1.3$ & $1.1 / 1.2$ & $14.3 /-$ & $50.0 / 12.5$ & $-\mid 50.0$ \\
\hline Unknown sigmoid & $0.1 / 0.2$ & $0.3 /-$ & $-1-$ & $-1-$ & $-1-$ & $-1-$ & $-1-$ & $-1-$ & $-1-$ & $-1-$ & $-1-$ \\
\hline Varicosporium elodeae W. Kegel & $0.6 / 0.5$ & $0.5 / 0.4$ & $-/ 0.2$ & $0.3 / 0.2$ & $0.4 / 0.1$ & $-/ 0.1$ & $-1-$ & $-1-$ & $-1-$ & $-1-$ & $-1-$ \\
\hline No. of species & $15 / 15$ & $16 / 14$ & $13 / 13$ & $16 / 14$ & $11 / 12$ & $12 / 13$ & $12 / 11$ & $12 / 9$ & $6 / 4$ & $3 / 3$ & $0 / 2$ \\
\hline No. of OTUs & $19 / 17$ & n.d. & $17 / 14$ & $18 /-$ & n.d. & $16 / 14$ & n.d. & $15 / 15$ & n.d. & n.d. & $9 / 10$ \\
\hline
\end{tabular}

n.d.: not determined. 

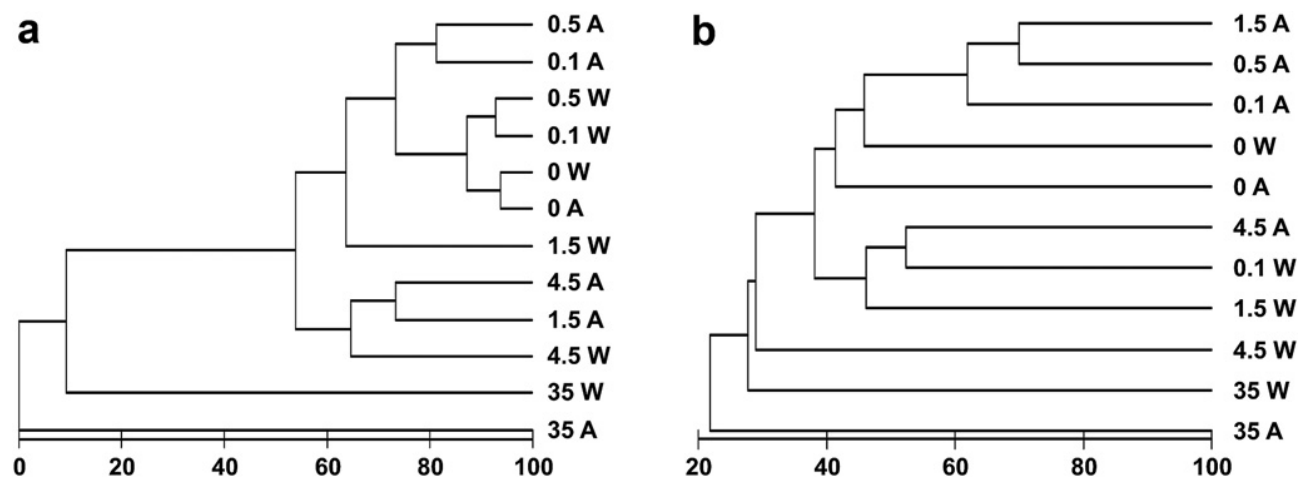

Fig. 1. Dendograms from fungal-sporulating species (a) and DGGE fingerprints of fungal DNA (b) on decomposing alder leaves colonized in the Algeriz Stream and exposed for 20 days in microcosms to different $\mathrm{Cd}$ concentrations $\left(0,0.1,0.5,1.5,4.5\right.$ and $\left.35 \mathrm{mg} \mathrm{L}^{-1}\right)$ at ambient temperature of $15{ }^{\circ} \mathrm{C}(\mathrm{A})$ and warming temperature of $21{ }^{\circ} \mathrm{C}(\mathrm{W})$. Clusters were constructed based on UPGMA analyses using the Pearson correlation coefficient.
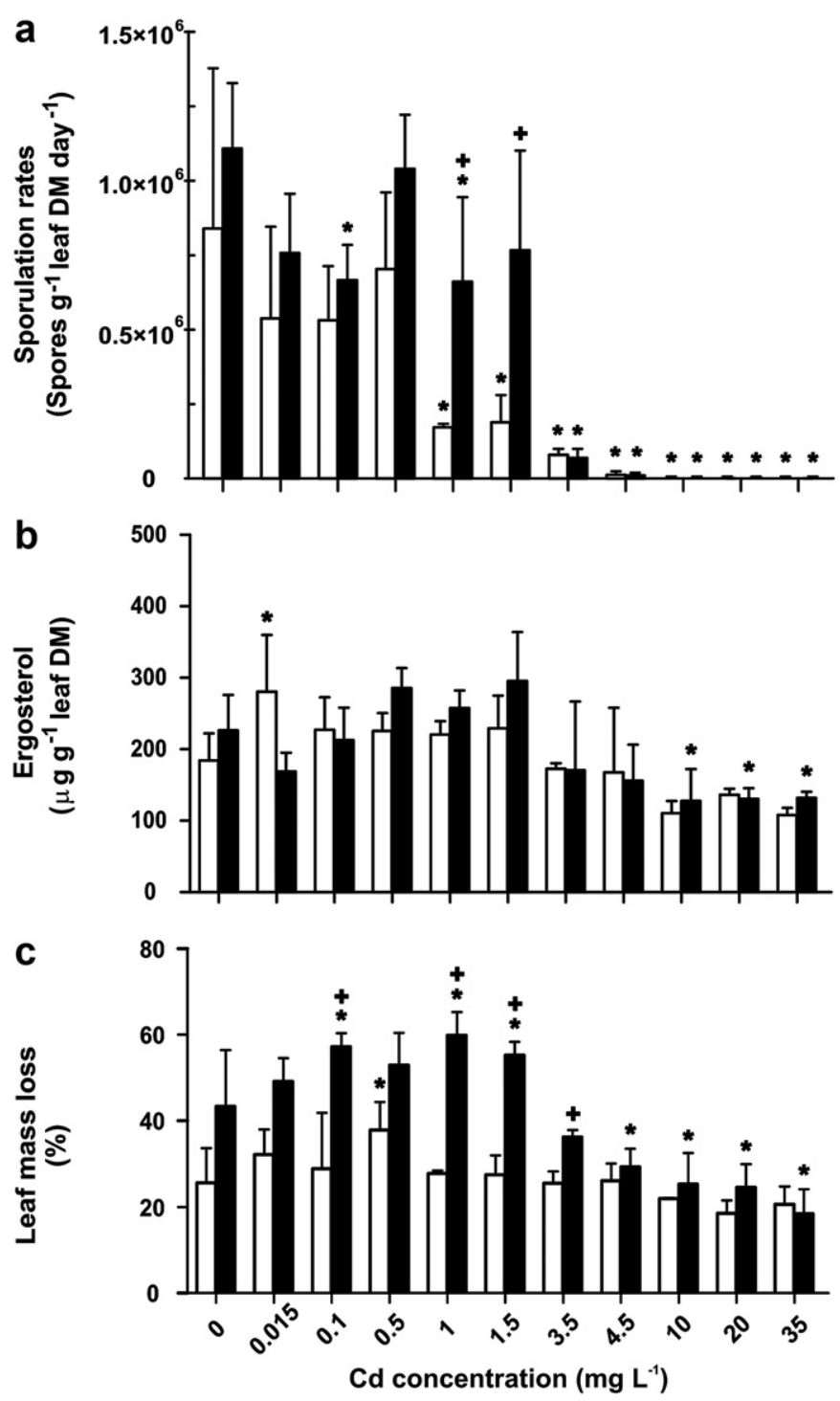

Fig. 2. Fungal sporulation rates (a), fungal biomass as ergosterol concentration (b) and mass loss of alder leaves (c) colonized in the Algeriz Stream and exposed for 20 days in microcosms to different $\mathrm{Cd}$ concentrations at ambient temperature of $15{ }^{\circ} \mathrm{C}$ (white bars) and warming temperature of $21{ }^{\circ} \mathrm{C}$ (black bars). *, significant effect of $\mathrm{Cd}$ comparing to control at each temperature; + , significant effect of temperature at each Cd level (two-way ANOVA, Bonferroni tests, $p<0.05$ ). M + SEM. fungal biomass at the highest temperature (Bonferroni tests, $p<0.05$ ).

In control microcosms at $15{ }^{\circ} \mathrm{C}$, alder leaves lost $26 \%$ of its mass in 20 days (Fig. 2C). Leaf mass loss was generally higher at $21^{\circ} \mathrm{C}$ than at $15{ }^{\circ} \mathrm{C}$ and was also affected by Cd (two-way ANOVA, $p<0.0001$ for both factors). The interaction between temperature and Cd was also significant $(p<0.0001)$. Leaf mass loss was stimulated at low $\mathrm{Cd}$ concentrations, but reduced at concentrations higher than $3.5 \mathrm{mg} \mathrm{L}^{-1}$ at the highest temperature (Bonferroni tests, $p<0.05$ ). At $15{ }^{\circ} \mathrm{C}$, no significant decrease in leaf mass loss was found. The $\mathrm{EC}_{50}$ of $\mathrm{Cd}$ for leaf mass loss was about 4 times higher at $15{ }^{\circ} \mathrm{C}\left(\mathrm{EC}_{50}=44.089 \pm 0.021 \mathrm{mg} \mathrm{L}^{-1}\right)$ than at $21{ }^{\circ} \mathrm{C}$ $\left(\mathrm{EC}_{50}=9.513 \pm 0.016 \mathrm{mg} \mathrm{L}^{-1}\right)$.

In microcosms without $\mathrm{Cd}$ addition, the relative consumption rates of alder leaves by the shredder Limnephilus sp. were 0.233 and $0.301 \mathrm{~g}$ leaf dry mass $\mathrm{g}^{-1}$ animal dry mass day ${ }^{-1}$ at $15^{\circ} \mathrm{C}$ and $21^{\circ} \mathrm{C}$, respectively (Fig. 3a). The relative consumption rate was stimulated by temperature and inhibited by $\mathrm{Cd}$, although the interaction between factors was significant (two-way ANOVA, $p=0.005$, $p<0.0001$ and $p=0.028$, respectively). Inhibition by Cd was stronger when animals were exposed to the highest metal concentration (Bonferroni tests, $p<0.05$ ). The concentration of $\mathrm{Cd}$ causing $50 \%$ reduction in the relative consumption rate of the shredder was higher at $15^{\circ} \mathrm{C}\left(\mathrm{EC}_{50}=3.643 \pm 0.015 \mathrm{mg} \mathrm{L}^{-1}\right)$ than at $21{ }^{\circ} \mathrm{C}\left(\mathrm{EC}_{50}=3.166 \pm 0.051 \mathrm{mg} \mathrm{L}^{-1}\right)$. The relative growth rate of animals was only significantly affected by temperature, with greater values for animals exposed to $21{ }^{\circ} \mathrm{C}$ (two-way ANOVA, $p=0.023$, Bonferroni tests, $p<0.05$ ) (Fig. 3b). At the end of the feeding experiment, higher concentrations of $\mathrm{Cd}$ were found in leaves followed by animal case and body (Table 2). Moreover, the accumulation of $\mathrm{Cd}$ at $21^{\circ} \mathrm{C}$ was consistently higher than at $15^{\circ} \mathrm{C}$ (Table 2).

In the post-exposure feeding experiment, animals were exposed to $\mathrm{Cd}$ ( 4 days) and then were released from the stressor and allowed to feed on leaves for 5 days at $15{ }^{\circ} \mathrm{C}$. In control microcosms, shredders consumed $54 \%$ of leaf mass in 5 days (Fig. 4). Leaf consumption by the shredders was strongly inhibited by preexposure to $\mathrm{Cd}$ concentrations $\geq 0.01 \mathrm{mg} \mathrm{L}^{-1}$ (one-way ANOVA, $p<0.0001$; Bonferroni tests, $p>0.05$ ). The $\mathrm{Cd}$ concentration inhibiting $50 \%$ of leaf consumption in the post-exposure feeding experiment was $0.161 \pm 0.045 \mathrm{mg} \mathrm{L}^{-1}$.

\section{Discussion}

Within the physiological range, biological processes, such as organismal growth and reproduction, are positively related to temperature (Fernandes et al., 2009a; Ferreira et al., 2010). This was 

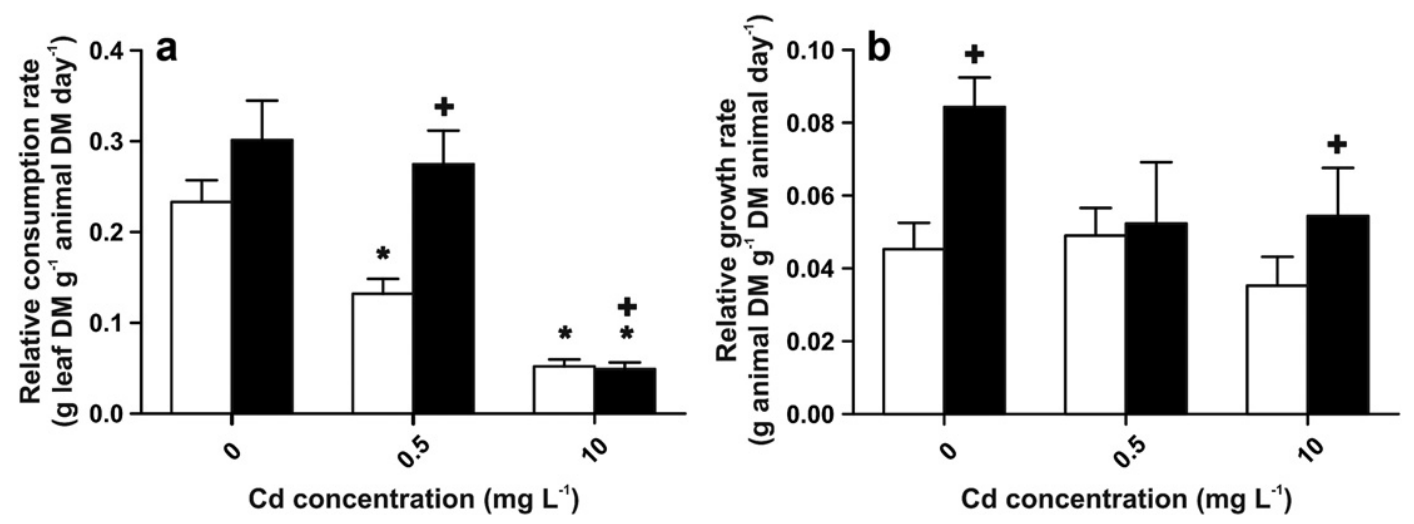

Fig. 3. Relative consumption rates of alder leaves (a) and relative growth rates (b) of the shredder Limnephilus sp. exposed to different Cd concentrations at ambient temperature of $15^{\circ} \mathrm{C}$ (white bars) and warming temperature of $21^{\circ} \mathrm{C}$ (black bars). ${ }^{*}$, significant effect of $\mathrm{Cd}$ comparing to control at each temperature; + , significant effect of temperature at each Cd level (two-way ANOVA, Bonferroni tests, $p<0.05)$. M + SEM.

confirmed in our study by the stimulation of both microbiallymediated litter decomposition and leaf consumption by the shredder Limnephilus sp. at the highest temperature $\left(21^{\circ} \mathrm{C}\right)$. The increase in the stream water temperature led to shifts in fungal species composition on decomposing leaves, probably because some species attained their upper thermal tolerance limit while others attained their optimum. These changes can affect litter decomposition because invertebrate shredders preferentially feed on leaves colonized by certain fungal species (Lecerf et al., 2005; Canhoto and Graça, 2008; Chung and Suberkropp, 2009).

The exposure to $\mathrm{Cd}$ led to a decrease in fungal reproductive activity and leaf decomposition, mainly at concentrations higher than $1.5 \mathrm{mg} \mathrm{L}^{-1}$. Although we recorded a higher number of fungal species based on DNA fingerprinting than on morphology of released conidia, $\mathrm{Cd}$ exposure decreased fungal species richness assessed by both methodologies, particularly at the highest concentrations. Some species of aquatic hyphomycetes are able to tolerate high levels of Cd (Guimarães-Soares et al., 2007; Azevedo and Cássio, 2010), but both diversity and reproductive (spore) activity of fungal decomposers on leaves can decrease under metal exposure (Sridhar et al., 2001; Krauss et al., 2003; Duarte et al., 2008; Moreirinha et al., 2011). However, at low Cd concentrations we found a stimulation of leaf decomposition by microbes. In low doses, both essential and non-essential metals are reported to have a stimulatory effect on reproduction and growth of several aquatic organisms (Calabrese and Blain, 2005; Lefcort et al., 2008; Shen et al., 2009). According to Chapman (2002), under low stress, organisms are able to repair cellular damages and can even overcompensate and reduce background damage more effectively. Indeed, many studies have reported a stimulation of biological

Table 2

Cadmium concentration in leaves and in the case and larvae of the invertebrate shredder Limnephilus sp. in microcosms supplemented or not with $\mathrm{Cd}$ at $15{ }^{\circ} \mathrm{C}$ and $21{ }^{\circ} \mathrm{C}$ for 6 days. Data represent the pool of 11 replicates.

\begin{tabular}{lll}
\hline & $\mathrm{Cd}$ added $\left(\mathrm{mg} \mathrm{L}^{-1}\right)$ & $\begin{array}{l}\mathrm{Cd} \text { measured }\left(\mathrm{mg} \mathrm{g}^{-1}\right) \\
15{ }^{\circ} \mathrm{C} / 21{ }^{\circ} \mathrm{C}\end{array}$ \\
\hline Leaves & 0 & $0.02 / 0.02$ \\
& 0.5 & $0.25 / 0.33$ \\
Case & 10 & $3.57 / 4.30$ \\
& 0 & $0.01 / 0.01$ \\
\multirow{2}{*}{ Larvae } & 0.5 & $0.05 / 0.06$ \\
& 10 & $0.65 / 0.89$ \\
& 0 & $0.00 / 0.00$ \\
& 0.5 & $0.02 / 0.02$ \\
& 10 & $0.05 / 0.12$ \\
\hline
\end{tabular}

responses (e.g. growth) at low doses of an inhibitor (Calabrese et al., 2007). This is known as hormesis and has been documented in microbes, plants and animals (Calabrese and Blain, 2005), but the implications of this phenomenon to ecological processes require further investigation.

Invertebrate survival and growth are commonly reported to be affected by Cd (Irving et al., 2003; Krauss et al., 2003; Wilding and Maltby, 2006; Brinkman and Johnston, 2008) and temperature (Turner and Williams, 2005; Ferreira et al., 2010). In our study, these two stressors affected the feeding behaviour of the invertebrate shredder Limnephilus sp. and effects were more pronounced at $21{ }^{\circ} \mathrm{C}$. Also, for both fungal sporulation and leaf decomposition, the concentration of $\mathrm{Cd}$ at which $50 \%$ of effects were observed was higher at $15{ }^{\circ} \mathrm{C}$ than at $21^{\circ} \mathrm{C}$, suggesting that higher temperatures lead to increased toxicity of $\mathrm{Cd}$. Elevated temperature and metal stress can, independently of each other, increase maintenance costs, reduce mitochondrial efficiency and impair the oxygen uptake and delivery to the tissues, leading to hypoxaemia and energy deficiency (Sokolova and Lannig, 2008). As a result, exposure to one of these stressors might sensitize organisms to the other stressor. Moreover, an increase in metabolic rates at elevated

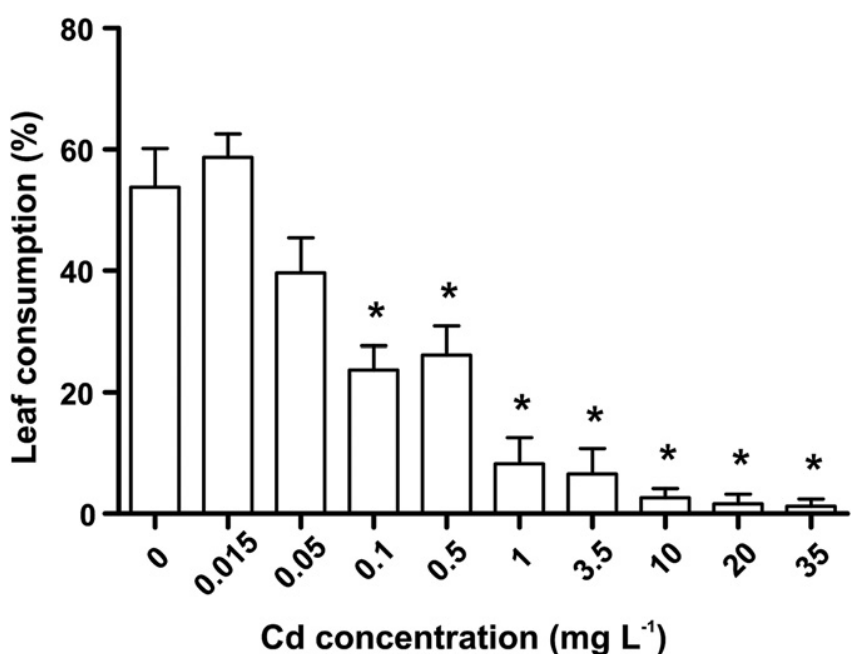

Fig. 4. Consumption of alder leaves during 5 days by the shredder Limnephilus sp. at $15^{\circ} \mathrm{C}$. The animals were previously exposed to different $\mathrm{Cd}$ concentrations for 4 days under starvation, before released from the stressor and supplied with noncontaminated leaves. *, significant effect of $\mathrm{Cd}$ comparing to control (one-way ANOVA, Bonferroni tests, $p<0.05)$. M + SEM. 
temperatures is often found (Sokolova and Lannig, 2008) and may contribute to metal accumulation due to a higher energy demand. Indeed, we found a greater accumulation of $\mathrm{Cd}$ in microbiallycolonized leaves and animals at the highest temperature probably contributing to a greater $\mathrm{Cd}$ toxicity. This may have implications in aquatic ecosystems, with possible consequences to water quality criteria for $\mathrm{Cd}$ in face of the ongoing global climate change.

In our study, fungal reproduction $\left(\mathrm{EC}_{50}=1.69 \mathrm{mg} \mathrm{Cd} \mathrm{L}^{-1}, 21^{\circ} \mathrm{C}\right.$ ) was the most sensitive measure to $\mathrm{Cd}$ exposure, followed by leaf

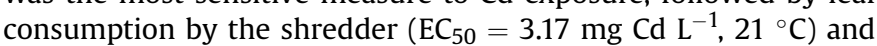
leaf decomposition by microbes $\left(\mathrm{EC}_{50}=9.51 \mathrm{mg} \mathrm{Cd} \mathrm{L}^{-1}\right)$. In natural freshwaters, Cd can occur at concentrations less than $0.1 \mu \mathrm{g} \mathrm{L}^{-1}$ (USEPA, 2001), but in metal-impacted streams higher concentrations have been reported (e.g., $67 \mu \mathrm{g} \mathrm{L}^{-1}$, Bervoets et al., 2005; up to $0.84 \mathrm{mg} \mathrm{L}^{-1}$, Lopes et al., 1999; $2.2 \mathrm{mg} \mathrm{L}^{-1}$, Sridhar et al., 2005 in the stream water; $29 \mathrm{mg} \mathrm{kg}^{-1}$, Krauss et al., 2005 in sediments), making the range of $\mathrm{Cd}$ concentrations tested here environmentally relevant.

Felten et al. (2008) found a $\mathrm{LC}_{50} 96 \mathrm{~h}=82.1 \mu \mathrm{g} \mathrm{Cd} \mathrm{L}{ }^{-1}$ for the aquatic shredder Gammarus pulex. Although we used Cd concentrations up to 10 times higher, we did not observe mortality after $96 \mathrm{~h}$ of exposure. A possible explanation for this can be attributed to the protective role of the case in the Limnephilus sp. Indeed, more $\mathrm{Cd}$ was associated with the case than with the larvae. Moreover, $\mathrm{Cd}$ accumulation in invertebrates has been more strongly correlated with metal content in food than in stream water or sediment (Beltman et al., 1999; Tessier et al., 2000). We demonstrated that Cd accumulated four times more in leaves than in animal case or body, probably explaining the strong inhibition of feeding activity of the invertebrate shredder at both temperatures. Metal toxicity is generally assumed to occur through waterborne exposure and environmental regulations do not take into account the potential impact of food as a source of metal contamination to aquatic organisms (Brinkman and Johnston, 2008). When metal exposure occurs via food in addition to via water, water quality criteria and standards may not protect organisms in aquatic environments. Hence, future studies on the effects of dietary versus aqueous exposure to toxicants on aquatic invertebrates would be helpful to clarify metal toxicity to biota and protect ecosystems in more realistic scenarios.

In our work, leaf consumption rates by the shredder Limnephilus sp. decreased until $60 \%$ when animals exposed to $\mathrm{Cd}$ ( $\leq 35 \mathrm{mg} \mathrm{L}^{-1}$ ) were released from metal stress and were allowed to feed on non-contaminated leaves. This agrees with other studies reporting a reduction in invertebrate feeding rates (17-90\%) after pre-exposure to metals (Moreira et al., 2005; Soares et al., 2005). Alterations in the feeding behaviour are known to influence the organism physiological performance, interfering with specific life-history events such as development, growth and reproduction, and eventually causing changes at the population and community level (Maltby et al., 2002). Although in our study the exposure to $\mathrm{Cd}$ did not lead to animal death up to $96 \mathrm{~h}$, invertebrate feeding activity was severely compromised. Therefore, the use of feeding rates as a sublethal endpoint might be a useful tool for assessing potential toxicity of contaminants in the environment.

Overall, our results showed that the increase in temperature stimulated microbial decomposition of leaf litter, fungal reproduction and leaf consumption by the shredder. Increased $\mathrm{Cd}$ concentrations inhibited reproduction and diversity of fungi, and leaf consumption by the invertebrate. The negative effects of $C d$ on fungal and shredder activity on leaves were more pronounced at the highest temperature. The combined effects of $\mathrm{Cd}$ and increased stream water temperature may compromise the diversity and activity of aquatic fungi and the feeding activity of sensitive shredders, with direct impacts to plant-litter decomposition and nutrient cycling in freshwaters. However, caution is needed when extrapolating results to natural ecosystems, because these are much more complex and variable than we can mimic in microcosm experiments. Although we found that higher temperature increased the toxicity of $\mathrm{Cd}$ to aquatic microbial decomposers and detritivores, the impacts of combined effects of chemicals and warming are still poorly understood. Because this type of information is relevant in the context of ongoing global change, further research is needed to better understand the current risks to freshwater biota and key ecosystem processes.

\section{Acknowledgement}

This study was supported by the Portuguese Foundation for Science and Technology through the projects PTDC/CLI/67180/2006 (FCOMP-01-0124-FEDER-007112) and PEst-C/BIA/UI4050/2011.

\section{References}

Azevedo, M.M., Cássio, F., 2010. Effects of metals on growth and sporulation of aquatic fungi. Drug and Chemical Toxicology 33, 269-278.

Azevedo-Pereira, H.V.S., Graça, M.A.S., Gonzalez, J.M., 2006. Life history of Lepidostoma hirtum in an Iberian stream and its role in organic matter processing. Hydrobiologia 559, 183-192.

Baldy, V., Chauvet, E., Charcosset, J.Y., Gessner, M.O., 2002. Microbial dynamics associated with leaves decomposing in the mainstem and flood plain pond of a large river. Aquatic Microbial Ecology 28, 25-36.

Barata, C., Baird, J.D., 2000. Determining the ecotoxicological mode of action of toxicants from measurements on individuals: results from short duration chronic tests with Daphnia magna Straus. Aquatic Toxicology 48, 195-209.

Beltman, D.J., Clements, W.H., Lipton, J., Cacela, D., 1999. Benthic invertebrate metals exposure, accumulation, and community-level effects downstream from a hard rock mine site. Environmental Toxicology and Chemistry 18, 299-307.

Bervoets, L., Voets, J., Covaci, A., Chu, S., Qadah, D., Smolders, R., Schepens, P. Blust, R., 2005. Use of transplanted zebra mussels (Dreissena polymorpha) to assess the bioavailability of microcontaminants in Flemish surface waters. Environmental Science and Technology 39, 1492-1505.

Brinkman, S.F., Johnston, W.D., 2008. Acute toxicity of aqueous copper, cadmium, and zinc to the mayfly Rhithrogena hageni. Archives of Environmental Contamination Toxicology 54, 466-472.

Calabrese, E., Blain, R., 2005. The occurrence of hormetic dose responses in the toxicological literature, the hormesis database: an overview. Toxicology and Applied Pharmacology 202, 289-301.

Calabrese, E.J., Bachmann, K.A., Bailer, A.J., et al., 2007. Biological stress response terminology: integrating the concepts of adaptive response and preconditioning stress within a hermetic dose-response framework. Toxicology and Applied Pharmacology 222, 122-128.

Canhoto, C., Graça, M.A.S., 2008. Interactions between fungi and stream invertebrates: back to the future. In: Sridhar, K.R., Bärlocher, F., Hyde, K.D. (Eds.), Novel Techniques and Ideas in Mycology. Fungal Diversity Press, Hong Kong, pp. 305-325.

Chapman, P.M., 2002. Ecological risk assessment (ERA) and hormesis. Science of the Total Environment 288, 131-140.

Chergui, H., Pattee, E., 1990. The influence of season on the breakdown of submerged leaves. Archiv für Hydrobiologie 120, 1-12.

Chung, N., Suberkropp, E., 2009. Effects of aquatic fungi on feeding preferences and bioenergetics of Pycnopsyche gentilis (Trichoptera: Limnephilidae). Hydrobiologia 630, 257-269.

Dang, C.K., Schindler, M., Chauvet, E., Gessner, M.O., 2009. Temperature oscillation coupled with fungal community shifts can modulate warming effects on litter decomposition. Ecology 90, 122-131.

Duarte, S., Pascoal, C., Cássio, F., 2004. Effects of zinc on leaf decomposition by fung in streams: studies in microcosms. Microbial Ecology 48, 366-374.

Duarte, S., Pascoal, C., Alves, A., Correia, A., Cássio, F., 2008. Copper and zinc mixtures induce shifts in microbial communities and reduce leaf litter decomposition in streams. Freshwater Biology 53, 91-101.

Felten, V., Charmantier, G., Mons, R., Geffard, A., Rousselle, P., Coquery, M., Garric, J., Geffard, O., 2008. Physiological and behavioural responses of Gammarus pulex (Crustacea: Amphipoda) exposed to cadmium. Aquatic Toxicology 86, 413-425.

Fernandes, I., Duarte, S., Pascoal, C., Cássio, F., 2009a. Mixtures of zinc and phosphate affect leaf litter decomposition by aquatic fungi in streams. Science of the Total Environment 407, 4283-4288.

Fernandes, I., Uzun, B., Pascoal, C., Cássio, F., 2009b. Responses of aquatic fungal communities on leaf litter to temperature-change events. International Review of Hydrobiology 94, 410-418.

Ferreira, V., Chauvet, E., 2011. Synergistic effects of water temperature and dissolved nutrients on litter decomposition and associated fungi. Global Change Biology 17, 551-564. 
Ferreira, V., Gonçalves, A.L., Godbold, D.L., Canhoto, C., 2010. Effect of increased atmospheric $\mathrm{CO} 2$ on the performance of an aquatic detritivore through changes in water temperature and litter quality. Global Change Biology 16, 3284-3296.

Gessner, M.O., 2005. Ergosterol as a measure of fungal biomass. In: Graça, M.A.S., Bärlocher, F., Gessner, M.O. (Eds.), Methods to Study Litter Decomposition: a Practical Guide. Springer, Dordrecht, Netherlands, pp. 189-196.

Gonzalez, J.M., Graça, M.A.S., 2003. Conversion of leaf litter to secondary production by a shredding caddisfly. Freshwater Biology 48, 1578-1592.

Graça, M.A.S., 2001. The role of invertebrates on leaf litter decomposition in streams - a review. International Review of Hydrobiology 86, 383-393.

Guimarães-Soares, L., Pascoal, C., Cássio, F., 2007. Effects of heavy metals on the production of thiol-compounds by the aquatic fungi Fontanospora fusiramosa and Flagellospora curta. Ecotoxicology and Environmental Safety 66, 36-43.

Heugens, E.H.W., Tokkie, L.T.B., Kraak, M.H.S., Hendriks, A.J., Van Straalen, N.M., Admiraal, W., 2006. Population growth of Daphnia magna under multiple stress conditions: joint effects of temperature, food, and cadmium. Environmental Toxicology and Chemistry 25, 1399-1407.

IPCC, 2007. Climate Change 2007: the Physical Science Basis. Contribution of Working Group I to the Fourth Assessment Report of the Intergovernmental Panel on Climate Change. http://www.ipcc.ch/ipccreports/ar4-wg1.htm.

Irving, E.C., Baird, D.J., Culp, J.M., 2003. Ecotoxicological responses of the mayfly Baetis tricaudatus to dietary and waterborne cadmium: implications for toxicity testing. Environmental Toxicology and Chemistry 22, 1058-1064.

Jentsch, A., Kreyling, J., Beierkuhnlein, C., 2007. A new generation of climate change experiments: events, not trends. Frontiers in Ecology and the Environment 5, 315-324.

Krauss, G., Sridhar, K.R., Jung, K., Wennrich, R., Ehrman, J., Bärlocher, F., 2003. Aquatic hyphomycetes in polluted groundwater habitats of central Germany. Microbial Ecology 45, 329-339.

Krauss, G., Sridhar, K.R., Bärlocher, F., 2005. Aquatic hyphomycetes and leaf litter decomposition in contaminated groundwater wells in central Germany. Archiv für Hydrobiologie 162, 417-429.

Lecerf, A., Dobson, M., Dang, C.K., Chauvet, E., 2005. Riparian plant species loss alters trophic dynamics in detritus-based stream ecosystems. Oecology 146, 432-442.

Lefcort, H., Freedman, Z., House, S., Pendleton, M., 2008. Hormetic effects of heavy metals in aquatic snails: is a little bit of pollution good? EcoHealth 5, 10-17.

Lopes, I., Gonçalves, F., Soares, A.M.V.M., Ribeiro, R., 1999. Discriminating the ecotoxicity due to metals and to low pH in acid mine drainage. Ecotoxicology and Environmental Safety 44, 207-214.

Maltby, L., Clayton, S.A., Wood, R.M., McLoughlin, N., 2002. Evaluation of the Gammarus pulex in situ feeding assay as a biomonitor of water quality: robustness, responsiveness and relevance. Environmental Toxicology and Chemistry 21, 361-368.

Moreira, S.M., Moreira-Santos, M., Guilhermino, L., Ribeiro, R., 2005. A short-term sublethal in situ toxicity assay with Hediste diversicolor (Polychaeta) for estuarine sediments based on postexposure feeding. Environmental Toxicology and Chemistry 24, 2010-2018.

Moreirinha, C., Duarte, S., Pascoal, C., Cássio, F., 2011. Effects of cadmium and phenanthrene mixtures on aquatic fungi and microbially mediated leaf litter decomposition. Archives of Environmental Contamination and Toxicology 61, 211-219.

Parmesan, C., Yohe, G., 2003. A globally coherent fingerprint of climate change impacts across natural systems. Nature $421,37-42$.
Pascoal, C., Cássio, F., 2004. Contribution of fungi and bacteria to leaf litter decomposition in a polluted river. Applied and Environmental Microbiology 70, 5266-5273.

Pascoal, C., Cássio, F., Marcotegui, A., Sanz, B., Gomes, P., 2005. Role of fungi, bacteria, and invertebrates in leaf litter breakdown in a polluted river. Journal of the North American Benthological Society 24, 784-797.

Petchey, O.L., McPhearson, P.T., Casey, T.M., Morin, P.J., 1999. Environmental warming alters food-web structure and ecosystem function. Nature 402, 69-72.

Rajashekar, M., Kaveriappa, K.M., 2000. Effects of temperature and light on growth and sporulation of aquatic hyphomycetes. Hydrobiologia 441, 149-153.

Riddell, D.J., Culp, J.M., Baird, D.J., 2005. Behavioral responses to sublethal cadmium exposure within an experimental aquatic food web. Environmental Toxicology and Chemistry 24, 431-441.

Schaller, J., Weiske, A., Mkandawire, M., Gert Dudel, E., 2010. Invertebrates control metals and arsenic sequestration as ecosystem engineers. Chemosphere 79, 169-173.

Shen, K., Shen, C., Lu, Y., et al., 2009. Hormesis response of marine and freshwater luminescent bacteria to metal exposure. Biological Research 42, 183-187.

Soares, S., Cativa, I., Moreira-Santos, M., Soares, A.M.V.M., Ribeiro, R., 2005. A shortterm sublethal in situ sediment assay with Chironomus riparius based on postexposure feeding. Archives of Environmental Contamination and Toxicology 49, $163-172$.

Sokolova, I.M., Lannig, G., 2008. Interactive effects of metal pollution and temperature on metabolism in aquatic ectotherms: implications of global climate change. Climate Research 37, 181-201.

Sridhar, K.R., Krauss, G., Bärlocher, F., Raviraja, N.S., Wennrich, R., Baumbach, R., Kraus, G.-J., 2001. Decomposition of alder leaves in two heavy metal-polluted streams in central Germany. Aquatic Microbial Ecology 26, 73-80.

Sridhar, K., Bärlocher, F., Krauss, G.-J., Krauss, G., 2005. Response of aquatic hyphomycete communities to changes in heavy metal exposure. International Review Hydrobiology 90, 21-32.

Suberkropp, K., Weyers, H., 1996. Application of fungal and bacterial production methodologies to decomposing leaves in streams. Applied and Environmental Microbiology 62, 1610-1615.

Tessier, L., Boisvert, J.L., Vought, L.B.M., Lacoursiere, J.O., 2000. Anomalies on capture nets of Hydropsyche slossonae larvae (Trichoptera; Hydropsychidae) following a sublethal chronic exposure to cadmium. Environmental Pollution 108, 425-438.

Turner, D., Williams, D.D., 2005. Sexual dimorphism and the influence of artificial elevated temperatures on body size in the imago Nemoura trispinosa (Plecoptera: Nemouridae). Aquatic Insects 27, 243-252.

USEPA, 2001. Update of Ambient Water Quality Criteria for Cadmium. United States Environmental Protection Agency. EPA-822-R-01-001.

Vogt, C., Belz, D., Galluba, S., Nowak, C., Oetken, M., Oehlmann, J., 2007. Effects of cadmium and tributyltin on development and reproduction of the non-biting midge Chironomus riparius (Diptera) - baseline experiments for future multi generation studies. Journal of Environmental Sciences and Health Part A 42, $1-9$.

Wang, Z., Yan, C., Zhang, X., 2009. Acute and chronic cadmium toxicity to a saltwater cladoceran Moina monogolica and its relative importance. Ecotoxicology 18, $47-54$.

Wilding, J., Maltby, L., 2006. Relative toxicological importance of aqueous and dietary metal exposure to a freshwater crustacean: implication for risk assessment. Environmental Toxicology and Chemistry 25, 1795-1801.

Zar, J.H., 1996. Biostatistical Analysis, third ed. Prentice-Hall, Englewood Cliffs, NJ. 